\title{
Concepts of pedagogy as an applied philosophy: Paul Natorp, John Dewey and Sergius Hessen
}

\author{
Wojciech HANUSZKIEWICZ*
}

\begin{abstract}
Paul Natorp, John Dewey and Sergius Hessen are usually considered to represent three different philosophical and pedagogical doctrines developed at the turn of the Twentieth century. These are, respectively: neo-Kantianism, pragmatism and humanistic pedagogy widely rooted in Wilhelm Dilthey's philosophy. Contrary to this common classification, Hessen himself described his own concept of pedagogy as an applied philosophy as a continuation of Natorp's thought. However, Hessen also noted that an approach very similar to his one can be found (with some restrictions) in John Dewey's theory. In this case, the fundamental issue is to determine the relationship between philosophy and pedagogical theory and practise. The main parts of this article will identify the specificity of this relationship: the specificity implied by the concept of pedagogy understood as applied philosophy. The concept of pedagogy, understood as an applied philosophy in its theoretical and practical aspects, is the basis for critical reconstruction of social life in general. It is the opinion shared by all three philosophers that this type of reconstruction should be based on the communal dimension of basic social interactions, that is, on the communal dimension of work. The only way for the renewal of a different form of social life leads through regaining through them an essential communal dimension of human work. All three authors agreed that to regain the communal dimension of human work by another form of social interaction would only be possible when certain conditions are present; that is, when work will be permeated by individual creativity. The presence of such conditions shall be ensured by the educational community. Thus, the educational community should be a starting and end point for any critical social reconstruction as well as for the pedagogy understood as an applied philosophy.
\end{abstract}

\section{KEYWORDS}

pedagogy and philosophy; neo-Kantianism; pragmatism; humanistic pedagogy; social pedagogy; educational community; work; creativity; reconstruction; social critique

* Ph.D., assistant professor at the Chair of Social Philosophy, Department of Philosophy and Sociology, Pedagogical University of Cracow. E-mail: wojciech.hanuszkiewicz@up. krakow.pl. 


\section{PRELIMINARY REMARKS}

Paul Natorp is certainly one of the most prominent thinkers in German pedagogy. It is a pity that he became a classic theorist of social pedagogy not because his work was thoroughly read and analysed but mostly on the basis of being quoted and mentioned on various occasions. Meanwhile, for his contemporaries he was undoubtedly a key figure, one who established the perspective - an important reference point - for independent research undertaken by the younger generation. The philosophical legacy of Natorp can be clearly seen in work of Edmund Husserl, Ernst Cassirer, Nicolai Hartmann and Martin Heidegger. The pedagogical aspect of Natorp's work had particular significance in two fundamental ways. The first aspect is Natorp's research into Johann Heinrich Pestalozzi's thought and his criticism of the herbartian model of teaching - at that time the prevailing pedagogical system in Germany (both in the theory and in the educational practice). It originated in the works of Johann Friedrich Herbart and his followers. Both aspects set the direction in which new pedagogical theories began to move. ${ }^{1}$ As such, Natorp can be considered not only a critic of the model of traditional school, but also a precursor to a new pedagogical orientation broadly understood to be an active school model. According to Natorp's fundamental belief, a student should be educated not through mechanical assimilation and reproduction of information, but through one's own creative work. Therefore, the teacher's task is primarily to organize school activities in such a way that this creative work becomes possible to its widest extent. Work, as it is stressed by the German philosopher, remains a basic social interaction. Hence, the second crucial aspect of Natorp's research focused on social conditions of educational processes. In this context, the Marburg philosopher was one of the key figures of the wide-scale movement (the so-called Reformpädagogik) that, at the turn of $20^{\text {th }}$ century, created the foundations of social pedagogy. ${ }^{2}$

Referring directly to the findings of Natorp, Russian philosopher Sergius Hessen - an educator who had lived and taught in Poland since

1 The most important works devoted to didactic ideas of Pestalozzi and criticism of Herbart's teaching model were collected in the book Gesammelte Abbandlungen zur Sozialpädagogik (Natorp, 1907). The Marburg philosopher also devoted a number of other publications to Pestalozzi's pedagogy (Natorp, 1909a; Natorp, 1919).

${ }^{2}$ In this respect, two of Natorp's works are especially important: Sozialpädagogik. Theorie der Willensbildung auf der Grundlage der Gemeinschaft (Natorp, 1920; the first edition of this work was published in 1899, I use the fourth edition) as well as Sozialidealismus. Neue Richtlinien sozialer Erziebung (Natorp, 1922; the first edition of this work was published in 1920, I use the second edition). The social and political context of Natorp's pedagogical activity was thoroughly analysed by Norbert Jagelka (Jagelka, 1992), while Carsten Müller (Müller, 2005) analysed all the most important concepts (including Natorp's) and the discussions around them in German social pedagogy of the turn of the Twentieth century. This author also presents apparent similarities between the German social pedagogy and Dewey's pedagogical project (Müller, 2005: 212-221). 
1935 - developed an interesting model of philosophical and pedagogical reflection. While trying to explicate the characteristic of this model, Hessen introduced the concept of pedagogy as an applied philosophy. ${ }^{3} \mathrm{He}$ also emphasized that this model can be found not only in Natorp's work, but also in John Dewey's work (Hessen, 1924: 6; Hessen, 1930a: 658). It is, however, true that the Russian philosopher immediately pointed out that Dewey's position on at least one issue is fundamentally different both from his own point of view and - what should be added - from the perspective adopted by Natorp. The American pragmatist rejected the static concept of the opposition between the ideality (of values) and the reality (of facts). Natorp and Hessen also rejected this static concept, following Hegel's solutions in the same way as Dewey. ${ }^{4}$ The author of Democracy and education also fully and correctly recognized the social nature of all educational practice. However, while studying philosophical and social issues sub specie generationis, Dewey rejected the perspective of eternity because he was able to perceive it only in its static structure. In this context, eternity is not a religious concept. It only indicates the timeless (überzeitig) validity of cultural values and meanings. ${ }^{5}$ According to Hessen, this is the greatest weakness of the entire philosophical and pedagogical project of the American pragmatist. Namely, he did not develop a dynamic concept of eternity, one that would remain free from all static (epistemological, ethical or metaphysical) dualism. By rejecting the perspective of eternity, Dewey was not able to adequately analyse the "contemplative" dimension of human life. Hessen emphasized that in only considering the contemplative dimension of human life are we able to see the whole dynamics of cultural and social changes not only sub specie generationis but also sub specie integrationis. This is an important consideration, as it was Dewey's idea to develop a similar, integrative approach. The Russian philosopher writes:

Dewey himself emphases the role of meaning understood as a factor due to which social activities and cultural creativity differ from purely natural development. An act

${ }^{3}$ On this issue drew the attention Natalia W. Daniłkina (Daniłkina, 2009). In this context, it should be emphasized that the Russian edition of Foundations of pedagogy has the subtitle: Introduction to an applied philosophy (Hessen, 1923).

${ }^{4}$ This is a problem which Dewey has already considered in his early works, written under the influence of Hegel (Dewey, 1975). However, it can be documented that this issue remained relevant in his later work (esp. Dewey, 1989a; Joas, 2000: 103-123). Not only Hegel's dialectics, but also Plato's dialectics, were particularly important for Natorp; Hessen referred to the same authors as well as to the Proudhon's model of dialectics (Natorp, 1912b; Natorp, 1921; Hessen, 1939: 315).

${ }_{5}^{5}$ This way Rudolf Hermann Lotze - and following him the Baden School of Neo-Kantianism - conceived the issue of validity. The philosophy of Heinrich Rickert - one of the leaders of this school - was particularly important for Hessen's pedagogical project (Hessen, 1935: 26). Cf. footnote 31 below. 
carrying the meaning cannot, however, be conceived of in one dimension of existence, it points out to some value that is embodied in being. It is the truth that cognition is neither a passive reflection of the external world, nor it is a predefined unravelling of the content of a priori concepts, but it is a creative activity. It is true that cognition is practically attached to some practical binding and it is only gradually that it is freeing itself from it. It is true that, even when cognition is liberated form this binding, it remains as an activity. However, the subject's activity is actually targeted to overcome purely biological life and surrender to the object, in order to continue unhindered in a higher spiritual life. Cognitive activity thus includes a factor of plunging into contemplation (Hessen, 1930a: 679). ${ }^{6}$

The basic problem here is then to develop such a concept of activity that could contain contemplation as its integral moment. Hessen writes in this context:

The idea of activity must be fully liberated from its unilateral connection with practicality as well as utility and in this and only in that aspect, the act of contemplation could be considered as its dialectical counterweight (Hessen, 1930a: 683).

"Biological 'instrumentalism”" (Hessen, 1930a: 658), which Dewey took as the basis of his pragmatism, is not incorrect, but, according to Hessen, incomplete. Contrary to that criticism, it can be shown that Dewey's pedagogical project, especially if we consider his two books published in 1934 (which Hessen could not have known when he was writing his paper ${ }^{7}$ ), is at least in one aspect very close to the solutions presented by Natorp and Hessen. The concept of creative work treated as a proper medium of education is a key contact point here. ${ }^{8}$ According to all three authors, the appropriate source of this medium is the educational community (bildende Gemeinschaft, Gemeinschaft der Bildung or Erziebungsgemeinschaft in Natorp's terms). ${ }^{9}$ In their pedagogical projects, this community is not only the original source of (civil) society, but is also an ideal that in this society should be rediscovered and reconstructed. ${ }^{10}$ Only this kind of reconstruction allows - in

${ }^{6}$ All translations from German and Polish into English are by the author of this paper.

7 There are: A common faith (Dewey, 1989a) and Art as experience (Dewey, 1989b).

${ }^{8}$ Regarding the aspect of creativity in Dewey's work, see especially: Joas, 1997: 138-144, 151-156; Joas, 2000: 103-123.

9 See esp.: Natorp, 1920: 88, 233; Natorp, 1925: 529. By referring to Natorp's Sozialpädagogik ( $\S \S 21,27)$, Hessen uses the term "legal community” (Hessen, 1935: 153). In the aforementioned fragments of his work, the German philosopher emphasized that the order of the educational community is regulated by the law and joint arrangements. Thanks to a common and equal to all law, a teacher can organize students' work in the classroom, which remains his main task (Natorp, 1920: 227-238, 283-288; Hessen, 1935: 119-154).

10 The concept of reconstruction is one of the key concepts of Dewey's pragmatism. The American philosopher defines education as "a constant reorganizing or reconstructing of 
this matter all three authors fully agree with each other — for the danger of a purely mechanical approach to social relations based on violence to be mitigated. This is possible when the process of reconstruction finds its proper expression in the educational community understood as the source initiating all transformations of social life. This role can be fulfilled by the community as far as it creates conditions conducive to the creative work of teachers and students. The goal of the analyses presented below is to show the concept of pedagogy as an applied philosophy from the perspective of its basic practical task - that is, the task of social reconstruction concentred around the communal dimension of creative work.

This issue is interesting because it allows us to see a common research perspective shared by representatives of various doctrines of pedagogical thought. These are usually considered almost completely separately. Natorp is widely recognized as the most important educator among representatives of neo-Kantianism; Dewey equally important as the creator of a pedagogy based on American pragmatism. Hessen is most often included among the representatives of humanistic pedagogy (geisteswissenschaftliche pädagogik). Humanistic pedagogy was developed extensively in Germany under the perceived influence of Wilhelm Dilthey's hermeneutics. ${ }^{11}$ However, the Russian philosopher and educator does not use these distinctions. Even if he defines his own position as a humanistic pedagogy (or as a pedagogy of culture ${ }^{12}$ ), his understanding of these terms is very broad, and he refers them to the concept of pedagogy as an applied philosophy (Hessen, 1997: 84). ${ }^{13}$

experience" (Dewey, 1985: 82). The concept of reconstruction remains also a very important category of the Natorp's project of critical psychology (Natorp, 1888; Natorp, 1912a). In his thought, however, it refers to the reconstruction of the subjective life of consciousness arising from various types of cultural objectifications. Dewey, on the other hand, is interested in the reconstruction of the pragmatic and social context of the human way of thinking and acting. Nevertheless, in relation to social life, the concept of reconstruction (Rekonstruktion, Neubau) appears in the late works of Natorp (Natorp, 1925: 509; Natorp, 1922: 107 — the last passage is, in extenso, cited below).

${ }^{11}$ In Polish works devoted to the history of $20^{\text {th }}$ century pedagogy, such classifications are very common. Compare: e.g., Sośnicki, 1967. (The author of this work, Kazimierz Sośnicki, was a Polish philosopher and educator who belonged to the Lvov-Warsaw School).

12 In the Polish pedagogical nomenclature, these terms (namely "pedagogika humanistyczna" and "pedagogika kultury") are synonymous.

${ }^{13}$ On this occasion, Dewey's pedagogy is also defined by Hessen as a pedagogy of culture. However, it should be noted, that Hessen kept contact with representatives of German humanistic pedagogy, mainly with Wilhelm Flitner and Eduard Spranger. In some of his works, Hessen used the notion of pedagogy of culture in this narrower sense. See for instance: Hessen, 1939: 224-225. 


\section{JOHN DEWEY'S CONCEPT OF PHILOSOPHY AS A THEORY OF EDUCATION}

In order to more accurately characterize this concept, Hessen (in an article devoted to Dewey) uses some phrases taken from Democracy and education, undoubtedly the most important pedagogical work produced by this American pragmatist. Hessen states:

Dewey sees pedagogy as the applied philosophy (angewandte Philosophie) that "offers an access straight into the human, as opposite to the technical meaning of philosophical discussions", indeed, "philosophy may even be defined as the general theory of education". "If a theory makes no difference in educational endeavor, it must be artificial. The educational point of view enables one to envisage the philosophic problems where they arise and thrive, where they are at home, and where acceptance or rejection makes a difference in practice". "On the other side, the business of schooling tends to become a routine empirical affair unless its aims and methods are animated by such a broad and sympathetic survey of its place in contemporary life as it is the business of philosophy to provide" (Hessen, 1930a: 658). ${ }^{14}$

The above approach to the pedagogy as an applied philosophy assumes that there is a mutual relationship between philosophy (theoretical reflection) and educational practice. On the one hand, philosophy provides the educational practice with a holistic, coherent horizon of thinking, thanks to which it is impossible to come up with a ready, fully defined action plan, but instead allows us to develop a perspective that helps — in Dewey's words to maintain:

the balance in a multitude of diverse actions, so that each borrows and gives meaning to every other. Any person who is open-minded and sensitive to new perceptions, and who has concentration and responsibility in connecting them has, in so far, a philosophical disposition (Dewey, 1985: 335).

Balance is a key concept here. It means the mutual relations and tensions between diverse actions that give these actions their proper meaning. In a similar context, Natorp used the concept of correlation. To grasp the correlation, i.e., the interrelationships that appears between diverse elements of the conceptual structure of experience, remains the task of transcendental deduction. The latter consists of justifying (grounding) the mutually conditioning means of these elements and demonstrating their indispensability for the cognitive process. According to the Marburg philosopher, pedagogy must be based on philosophy in all its scope because only philosophy can, thanks

14 Democracy and education is cited based on the following edition: Dewey, 1985: 338-339. Hessen used the first edition of this work from 1916. 
to deduction, demonstrate the validity of laws that govern "the creative work of culture" (Natorp, 1912b: 197). Pedagogy's task is to "apply" these laws to a specific educational situation. Hence, Natorp defined pedagogy as "concrete philosophy" (Natorp, 1909b: 48). Of course, the balance mentioned by the author of Democracy and education cannot be achieved through transcendental deduction, but through the dynamics of social processes. However, the "detranscendentalised "use of reason", ${ }^{15}$ which the American philosopher advocated for, also needs the criterion of its legitimacy. In this context, Dewey emphasized, philosophy must become concrete in its educational application. If it loses contact with educational practice then it turns into idle, purely theoretical speculation:

Education is a lab in which philosophical distinctions become concrete and are tested. It is suggestive that European philosophy originated (among the Athenians) under the direct pressure of educational questions. The earlier history of philosophy, developed by the Greeks in Asia Minor and Italy, so far as its range of topics is concerned, is mainly a chapter in the history of science rather than of philosophy as that word is understood to-day. The most penetrating definition of philosophy which can be given is, then, that it is the theory of education in its most general phases. The reconstruction of philosophy, of education, and of social ideals and methods thus go hand in hand (Dewey, 1985: 339, 341).

The concept of philosophy presented by Dewey in this way can certainly seem surprising. Here, the philosophy as such is explicitly identified with the philosophy (theory) of education (Sośnicki, 1967: 89-90). It is only through educational practice that philosophical reflections can gain vivid contact with social reality; meaning that, on the one hand, philosophical reflection can influence social reality, and, on the other hand, it can be tested and modified by social reality. Concreteness (applicability) doesn't join philosophical reflection from the outside only when there is a problem of implementation of fully ready theoretical solutions. This moment of applicability constitutes the specificity of philosophical reflection and as such is present from the very beginning, giving philosophy its concrete and critical character. Dewey believes that this understanding of philosophy has already appeared in ancient Greece; pragmatism at least in this matter - is a faithful continuation of the Greek way of thinking. Natorp and Hessen have similar understandings of their own concepts. ${ }^{16}$

However, philosophy (the theory of education) achieves its specific and concrete character not by particularizing some general structures or laws that

15 The term comes from Jürgen Habermas (Habermas, 2008: 24).

${ }^{16}$ In this context, Plato's theory of virtues played a key role in the pedagogical projects of both philosophers See: Natorp, 1920; Hessen, 1968a. For Natorp, see: Lembeck, 1994: 285-300; for Hessen, see Wieczorek, 2005: 40-41, 81-91 (for Dewey's concept of virtue see also Müller, 2005: 234-236). 
could be attributed with objective validity - Dewey was always an opponent of objectivist theory of value - but by rooting itself in social communication. However, social communication cannot here be understood purely instrumentally. The processes of communication may undoubtedly have an instrumental character, but as such, they do not have educational value. They possess educational value when they become the medium rooting communicating individuals in the community. The American philosopher writes:

Society does not only continue to exist by transmission, by communication, but it may fairly be said to exist in transmission, in communication. There is more than a verbal tie between the words common, community and communication. [...] Not only is social live identical with communication, but all communication (and hence all genuine social life) is educative. To be a recipient of a communication is to have an enlarged and changed experience. One shares in what another has thought and felt and in so far, meagrely or amply, has his own attitude modified. [...] All communication is like art. It may fairly be said, therefore, that any social arrangement that remains vitally social, or vitally shared, is educative to those who participate in it. Only when it becomes cast in a mould and runs in a routine way does it lose its educative power (Dewey, 1985: 7-9).

The educational experience is therefore always a community experience of participation in communication. It is precisely this moment of participation that allows us to regard the communication itself as a kind of art that counters ossified, routine, and instrumental behaviours. The latter are accompanied by communication, but communication is then used only to replicate ready-made schemes that block genuine social life. Only genuine social life allows the intellectual, volitional and emotional attitudes of participants in communication to be modified based on new common understanding (Dewey, 1985: 7) of the situations and problems faced by them. It is only through a moment of mutual understanding that the social process of communication can lead to a renewal (Dewey, 1985: 4) of the entire social life. Only then can communication become the art and foundation of the educational experience based on participation. ${ }^{17} \mathrm{~A}$ key concept here is the art, which Dewey understood as a specific quality of experience. This quality, permeating the entirety of human activity, triggers the pursuit of the creative consummation. ${ }^{18}$ In his work Art as experience, Dewey claimed:

17 In his Experience and nature, Dewey wrote: "Of all affairs, communication is the most wonderful. The things should be able to pass from the plane of external pathing and pulling to that of revealing themselves to man, and thereby to themselves; and that the fruit of communication should be participation, sharing, is a wonder by the side of which transubstantiation pales" (Dewey, 1988a: 132).

18 While presenting Dewey's aesthetic, I use the works of Hans Joas (cf. footnote 8) and Krystyna Wilkoszewska (Wilkoszewska, 2003). 
Art is quality that permeates an experience; it is not, save by a figure of speech, the experience itself. Esthetic experience is always more than esthetic. In it a body of matters and meanings not in themselves esthetic, become esthetic as they enter into an ordered rhythmic movement toward consummation (Dewey, 1989b: 329).

The pursuit of consummation is a determinant of aesthetic experience, but it can permeate all kinds of experience. To the extent that it is revealed in different kind of experience, the experience takes on the character of the aesthetic experience. This pursuit is already embedded in the most primal form of human activity, children's play. Therefore, if education in its fundamental dimension is the art of communication, the element of children's play must permeate it as well. Of course, educational experience cannot be based solely on play. In its most important dimension, the educational experience is the experience of working together. Work can gain its pedagogical meaning only when it becomes, thanks to its quality, art. That is, when it is infused by the element of play understood as the activity in which the child finds the consummation, the fulfilment:

Work is psychologically simply an activity which consciously includes regard for consequences as a part of itself; it becomes constrained labor when the consequences are outside of the activity as an end to which activity is merely a means. Work which remains permeated with the play attitude is art - in quality if not in conventional design (Dewey, 1985: 214).

The distinction between work and constrained labour is very important to Dewey's entire educational project. The difference between the two types of activities lies in the fact that constrained labour remains only a means to an objective that is externally imposed and unrelated to this activity. At work, on the other hand, the pursuit of objective comes from within. The distinction between the objectives and means is maintained in work, but neither are external to each other. The original objective may take a role of means at any time, and from the use of means may emerge new objectives. The elements that have already functioned as the means may become new objectives. The very modification of perspective that allows the transition from constrained labour to creative work becomes a fundamental challenge for pedagogy. In order to make this modification possible, the importance of a child's creative moment of play must be considered in the educational process. The educational community must grow organically out of the form of childhood social engagement, that is, playing with peers. Only in such conditions does work become art, i.e., the form of communication, which has aesthetic and educational value.

Communication therefore remains essential not because of its specific content, but because of communication itself. It is the original form of communal engagement, as it always remains an act of expression that is individual and at 
the same time intentionally directed to others. It is in creative expression, as he indicated in his work on aesthetics, that Dewey considered to be the right foundation for the entire social and cultural life of humans (Dewey, 1989b: 64-110). It is only human expressiveness that can link all the meanings of past experiences with present experiences. In the act of expression, the original intentions of the creator - based on his past experience - shape the material in which they are to be expressed, but work on this material often modifies these intentions in a very significant way. The material - whether marble or language - sets new goals for the artist through its resistance or other features. The creative act of expression thus transcends rigid (static) opposition between subject and object or between means and objective. In this act, what was supposed to be just a means of expression begins to build the very act of expression in a new creative way, thus a completely new perspectives emerge, ones that the artist was not aware of before. This act of expression, which remains the basis of all artistic approaches and art in general, is not the exclusive domain of creators and artists. A similar work must be done by every child and every student, as long as they engage in play with their peers or teamwork at school. The only difference between the situation of a child, a student or an artist lies in a scale of the difficulty of the tasks we face in each of these situations.

Capturing the tensions between the various components of an expressive act is not a work of consciousness, but of imagination. The role of consciousness remains very important. But it is limited to the proper preparation of the creative, holistic and intuition-based work of the imagination. Only imagination and work, not self-conscious thinking, are able to create something completely new from past experiences and their meanings. The aesthetic experience, with its fullest expression found in the experience of art, is characterized by this particular tension. On the one hand, it reveals the distinctive, fully individual and unique idiom of the work of art; on the other hand, this idiom is to be grasped only in the infinite background or the horizon, which saturate all the elements of the work, giving them a qualitative unity. Dewey wrote:

The different elements and specific qualities of a work of art blend and fuse in a way which physical things cannot emulate. This fusion is the felt presence of the same qualitative unity in all of them. "Parts" are discriminated, not intuited. But without the intuited enveloping quality parts are external to one another and mechanically related. Yet the organisation which is the work of art is nothing different from its parts or members. It is the parts as members - a fact that again brings us to the one pervasive quality that remains the same quality in being differentiated. The resulting sense of totality is commemorative, expectant, insinuating, premonitory. There is no name to be given it. [...] It is an idiom in which the particular work is composed and expressed, that which stamps it with individuality. It is the background which is more than spatial because it enters into and qualifies everything in the focus, everything distinguished as a part and member (Dewey, 1989b: 196-197). 
This opening to infinity - available to the subject only in the form of a holistic intuition - becomes for aesthetic experience a determinant of its specificity. Experience, in its narrowly practical (instrumental) concept, is an experience that gets us used to, as the American philosopher writes:

to think of physical objects as having bound edges, things like rocks, chairs, books and houses; trade and science, with its effort at precise measurement, have confirmed the belief. [...] We suppose the experience has the same definite limits as the things with which it is concerned. But in any experience, the most ordinary has an infinite total settings. Things, objects are only focal points of a here and now in a whole that stretches out infinitely. This is the qualitative "background" which is defined and made definitely conscious in particular objects and specified properties and qualities. There is something mystical associated with the word intuition and any experience becomes mystical in the degree in which the sense, the feeling, of the unlimited envelope becomes intense - as it may do in experience of the object of art (Dewey, 1989b: 197).

Aesthetic experience or aesthetic intuition should thus be embedded in every experience in which the subject is artistically engaged (Dewey, 1989b: 11), whether it be a mechanic in the factory, a teacher in the classroom, a scientist in the laboratory or a painter in the studio. This artistic commitment to the performing arts (also technical art) distinguishes a specialist from a dilettante. If we understand art in this way, we will be able to create - argued the author of Democracy and education - a social environment in which the arbitrary divisions between elite art and culture, and popular art, applied art or technical civilization can disappear. These divisions, as well as the division between children's play and adults' daily lives, are merely an expression of discriminatory social stratification. ${ }^{19}$ Dewey argues that contrary to stratification, it is necessary to create a theory of works of art "that reveals the way in which these works idealize qualities found in common experience" (Dewey, 1989b: 17). Therefore, only aesthetic qualities, insofar as they are able to be revealed in everyday experience, are allowed to develop a new holistic and concrete (intersubjective and individual) perspective of human activity; human activity, which would go beyond all the dividing and stratifying factors that inhibit social and individual development. The process of imaginative idealization, which makes such a new perspective possible at all, stems from the nature of aesthetic experience, i.e. from its qualitative unity, totality and continuity. ${ }^{20}$

${ }^{19}$ Dewey wrote extensively on the separation of colloquial experience from aesthetic experience in capitalist society in the first chapter of Art as experience (Dewey, 1989b: 14-17). Therefore, his own concept of aesthetics is essentially an attempt to solve the problem of "recovering the continuity of esthetic experience with normal processes of living" (Dewey, 1989b: 16).

20 The social significance of Dewey's process of idealization is discussed extensively in his work $A$ common faith (Dewey, 1989a). Dewey regards the very idealization and the practically 
If we look at Dewey's project of pedagogy as an applied philosophy, we will be able to easily discover from this perspective the far-reaching parallels between the analyses of the American philosopher and the pedagogical projects of Natorp and Hessen. Both Natorp and Hessen definitely did not attribute much significance to the problem of communication. However, it can be shown that their own views of pedagogy as an applied philosophy also focused on the issue of creative expression. In their view, creative expression is also the proper key to change the basic social interaction, which is work, into creative work, i.e., into work that is not only an appropriate medium of education, but can also be regarded as a fundamental factor in the renewal of social life.

\section{PAUL NATORP'S SOCIAL PEDAGOGY}

In his Sozialpädagogik, Natorp emphasized that the educational community cannot be identified with any existing community, because the educational community remains only an idea that expresses an ideal, ethical obligation (Sollen). This idea can gain its validity only if it is treated as an ideal, and thus an "infinite task" (unendliche Aufgabe) underlining all forms of the development of a social life (Natorp, 1909b: 129; Natorp, 1920: 295). Compared to this idea, all existing communities are imperfect. If, following Kant, we recognize that this idea means the full autonomy of both the community itself and all its members, then we must recognize all genuinely existing communities as burdened with various forms of heteronomy. Autonomy is the possibility of establishing our own laws, while heteronomy means being subject to foreign laws imposed on us by circumstances independent of our will. In this context, Natorp emphasized that the experience of heteronomic enslavement is the original social experience. The latter is embedded in the social structure of work. It should also be the starting point for social pedagogy. The basic task for social pedagogy is to organize the educational community in order to transform of social relations - both in the classroom and outside the classroom - in such a way that, thanks to their own work (experienced at first as an external constraint), individuals will be able to overcome heteronomy and will gain their autonomy while becoming members of the autonomous community (Natorp, 1920: 96, 176).

In his Sozialpädagogik, Natorp emphasised that the educational community in its original dimension remains a language community that is based on dialogical relations between I and You. (Natorp, 1920: 88-91). The subject gains his self-awareness only through mutual relationships with other subjects. The educational community cannot be considered only from a purely theoretical

actualize belief in the imaginative ideals of communal (democratic) life as the fundamental dimension of the religious value of experience. 
(scientific) point of view because language is "a direct expression of every cultural community (geistliche Gemeinschaft)" (Natorp, 1920: 278). As such, it contains, from the very beginning, elements of logical structure and interpersonal obligation of an ethical and aesthetic nature. Language also creates the first form of their unification. That way, for pedagogy, it becomes an indispensable medium of all cultural tradition (Natorp, 1920: 313-314). Linguistic objectifications, however, are imperfect in the sense that the concepts and relations, which are expressed in natural language, are mixed up in it. Therefore, all components of the conceptual structure need to be reconstructed in proper order (Natorp, 1920: 309). ${ }^{21}$ In this approach, the language itself becomes more of an object of creative work than the creative work's medium.

However, Natorp's approach to the role of language in education changed during the last period of his philosophical and pedagogical activity. In Sozialidealismus, he introduces a distinction between language (Sprache) and speaking (Sprechen or Aussprechen). He still understood language as the first, but highly imperfect cultural objectification, while he considered speaking to be an creative act (or a creative form) of expression. ${ }^{22}$ This act is present in children's behaviour from the very beginning; that is, in the most basic form of social interaction, which is children's play (Spiel). The German philosopher continued to emphasise - as he had already done in his Sozialpädagogik — that the basic social relationship is work. In this context, children's play should be understood as a "free introductory draft of work (frei bewegliche Vorzeichnung), which starts from purely inner point of the self-creating power (selbstschafende Kraft) and always goes back there" (Natorp, 1922: 107).

If the free creative act, characteristic of a child's expression and play, is to be transformed into the process of creative work (creative in the exact sense of the word), then the transformation itself must occur spontaneously, i.e. cannot be induced by any purely external (methodical or pedagogical) means. The task of pedagogy, therefore, is merely to remove obstacles that inhibit a child's spontaneous actions (Natorp, 1922: 107, 245). According to Natorp, "the healthy reconstruction of education" (das Ganze des gesunden Neubaues der Erziebung) (Natorp, 1922: 107) leading to the renewal of social life boils down to this re-extraction of the potential of human creativity, expressed in its original

${ }^{21}$ This reconstruction should be subject to the autonomous laws of creative work of culture. These laws should, of course, be applied to the particular educational situation. Natorp emphasised, however, that it is not possible to provide such top-formulated rules that would allow for this type of concrete, particular application. In this matter, the teacher must rely on his pedagogical tact, which can be developed only through practice. Knowledge of methodological and psychological rules is very helpful here, but it can only play an auxiliary role (Natorp, 1909b: 56-58).

22 In Natorp's words, the act of expression should be understood as a "self-shaping form that dynamically develops itself" (sich selbst prägende Form, die lebend sich entwickelt) (Natorp, 1922: 87). 
in children's play. This renewal would not be imposed top-down but instead would occur spontaneously "bottom-up" (von unten auf) (Natorp, 1922: 107). It would involve the transformation of the entire social work process, which largely remains a non-creative (mechanical and enslaving) process, into a creative process.

It would be wrong to understand this as the need to remove all subordination to laws or instructions from the work process. The point is that the relation between subordination and superiority itself, which Natorp captured with the Hegelian figures of master and servant (Natorp, 1922: 110-112), needs to be transformed from a heteronomical relationship into a communal relationship. This is only possible when the act of ordering commands or instructions, and the act of their execution, result not from a relationship of superiority or subordination but is a consequence of serving a common cause. The one who gives the orders gives them only because he understands the matter; he can, moreover, vouch for that understanding and take responsibility for it. The education process is largely a process in which individuals learn to be responsible for themselves, the community in which they participate, and the projects (the issues) they work on together.

Natorp, in both of his works, in Sozialpädagogik, as well as in Sozialidealismus - emphasized the importance of relationship between I and You (Natorp, 1922: 196, 212-213). However, while in the first of these works this relationship was important because it represented a moment of awakening of self-awareness of the subject, ${ }^{23}$ in the later work, it represents a moment of a direct opening of the subject to the world around him (Umwelt), as well as a moment of opening the world towards the subject. This opening moment remains crucial. This child's openness and sensitivity is his "inner, original strength" (innere Quellkraft) and his "most primary talent" (ursprünglichste Begabung); it is in these that the child's creative potential, through which child express himself, is revealed (Natorp, 1922: 85). True creativity, if it occurs at all in adult life, must be characterised by this kind of openness and sensitivity. Creativity is never simply a passive adaptation to some pre-existing, external, or alien condition or circumstance. In this regard, the German philosopher stressed that the creative intuition does not refer to anything besides itself (Natorp, 1922: 107); that is, it refers only to a completely new opening of the subject to the world around him, as well as the opening of the world towards the subject. Thanks to the act of creativity, both the world and the subject begin to appear in their mutual dialogic relationship - a relationship both fully individual and fully communal - in a completely new way that could not have been foreseen prior to that act.

${ }^{23}$ The indelibly dialogic nature of this moment was highlighted as early as the 1890 s by Johann Gottlieb Fichte, and Natorp clearly follows in his footsteps in this regard. 
The creative work has its proper source in the intuitive opening of the subject to his fully individual way of being, through which he participates in the world around him. The author of Sozilidealismus understood intuition (Anschauung, Intuitus) as a non-discursive (non-expressible through conceptual means) moment of creativity, ${ }^{24}$ which remains a kind of knowledge of how to act in particular time and in particular situation. But this knowledge can only minimally, if at all, be a subject of conceptual understanding. ${ }^{25}$ It can be neither induced nor produced by discursive (methodological) means alone. Because of this intuition and unpredictability, the moment of creativity can therefore be described as "grace, conception, inspiration", fully individual in its character (Natorp, 1922: 245). ${ }^{26}$ The moment of creative inspiration, although always fully individual, becomes at the same time the moment through which the subject begins to participate creatively (expressing himself through his own actions) in the world around him. Thus, this moment from the very beginning has its own communal dimension. This fully individual and concrete, yet at the same time fully communal, dimension of the individual creativity must be recognised as a fundamental problem of pedagogy. It also gives pedagogy as an applied philosophy its proper critical importance. The philosophical and pedagogical "moment of application" can fulfil its critical function in relation to other types of human activity only in so far as it is able to include the moment of creativity (Schöpfung, poiesis) of all the members of the educational community. Creativity is understood here exactly as having a character that is both fully individualizing as well as fully inclusive.

${ }^{24}$ Natorp extracted such an understanding of intuition as fully creative and active (not containing of element of idleness, passive reproducing, mimicking of something that has been already been given) from the pedagogical writing of Pestalozzi, mentioned here explicitly. $\mathrm{He}$ further stressed that institution itself shall be understood not so much as a static moment, $A n-$ schauung, but as a pure activity Anschauen, or even Sichbineinschauen (Natorp, 1922: 106-107). For further understanding of this problem of Anschaung in Pestalozzi's view, see Natorp, 1919: 12-133.

${ }^{25}$ For this very reason, in his later lectures Natorp distinguished between the ethics of duty (Etbik des Sollens), which can be captured in conceptual structures, and the ethics of being (Ethik des Seins) fully dependent on unique situations and accessible only by intuition (Natorp, 1958: 365). Only the latter can grant the ethical practice a fully free and individual character. The greatest downside of the analysis presented in the Sozialpädagogik is, according to Natorp itself, that it fail to take full account of this individual perspective of ethical freedom, which as such always remains the freedom of education and thus can also become the basis of the educational community (Natorp, 1925: 518-519).

${ }^{26}$ Moreover, Natorp granted the speculative or religious-mystical meaning to creativity understood as grace or gift. The creative act of expression he interprets from the perspective of the Biblical utterance of the Word (Wort), as mentioned in a Prologue of the Gospel of John (Natorp, 1922: 244-246, and also: 213-215). 


\section{SERGIUS HESSEN ON UNITY AND CONTRADICTIONS OF EDUCATION}

In a similar way, the critical potential of pedagogy as an applied philosophy is recognised by Hessen. In his Foundation of pedagogy (directly referring to Natorp's Sozialpädagogik), Hessen defined the educational community as the legal community. ${ }^{27}$ It should be stressed that in Hessen's view, the law is not equal to a collection of legal acts issued by relevant state institutions. Referring to Leon Petrażycki's theory of law, Hessen pointed out that we can talk about legal conduct in any situation where human actions are motivated by a specific legal emotion. ${ }^{28}$ This emotion:

like moral emotion, includes the experience of duty. But when in moral emotion duty is experience as a pure command (imperative), in a legal emotion it is experienced as a command which fulfilment is someone's obligation, as if is someone's assignment (attribute). [...] Thus, the norms of morality are imperative, whereas the norms of law are both imperative and attributive. Every obligation corresponds in law to someone's request, and vice versa: every law corresponds to someone's obligation (Hessen, 1968b: 296-297).

All mutual obligations are part of the law; that is, among other things, the rules of cooperation established on an ongoing basis. Such rules do not need to be codified in any way in order to be the law. With this understanding of law, the educational community can be classified as a legal community. With regards to the educational community, the teacher's job is primarily to properly organise student work. The work is to be organised in such a way that each student can as far as possible express through work his individual personality. Hessen sees the essence of the educational process in the formation of a student's autonomous personality. The school of work should serve this purpose. Personality can only be expressed and shaped by a student's specific social, scientific and cultural activities. The Russian philosopher clearly emphasised that the school of work:

When considering the development of a student's personality through his participation in a class's work, $[\ldots .$.$] must paid particular attention to the student's ability to express$ in external symbols his inner and spiritual content, as well as the results of his personal observations and thought processes. Drawing, as well as manual work, is as worthy and powerful means of expression as words (Hessen, 1935: 136).

27 See footnote 9.

${ }^{28}$ A Polish disciple of Hessen, Andrzej Walicki (Walicki, 1992), wrote about Petrażycki and Hessen's philosophy of law (which was included in the broad context of the philosophy of law of Russian liberalism). In this perspective, Hessen's philosophy of law should be compared with the philosophy of law developed by Natorp and Dewey. However, this issue goes far beyond the problem framework of the analyses presented here. 
Like Dewey and Natorp, Hessen's model of pedagogy as an applied philosophy considered the problem of creative expression to be a critical issue. However, he didn't elaborate on this problem. In contrast, he strongly emphasized the role of the teacher. The teacher's activity was intended to lead to the development of students' creative expression. From this perspective, Hessen defined the process of education as the process of forming the full subjective autonomy of the students. He added that autonomy should be understood as a synthesis of anomie and heteronomy. Anomie is characterized by the primal element of a child's imagination (fantasy), which is unable to conform to a particular purpose or law. This subordination remains characteristic only for the heteronomy (lessons at school should be characterized by it). In turn, the entire educational process finds its culmination in the personal autonomy of the learning subjects. We can see here a triad, already formulated by Natorp, of anomie-heteronomy-autonomy. ${ }^{29}$ Hessen stated:

Separate moments of play, not defined by any purpose for which they would be the means, are devoid of consistency, internal consistency and regularity. Child's play can constantly change its course depending on external sensations; it can start over and over again, stop freely anytime without any problem. This is what differs play from work. Work, always pursuing some external goal, is always subject to some internal law. But work itself can be twofold. The purpose designating the work's exactness, can be assign from the outside, it can be set by others: then we have a heteronomic activity, e.g. a lesson. Or the purpose of a human producing work can be set by himself as something that only he can, and therefore should, fulfil at that time - in such case we have an autonomous activity of creative work. In the hierarchy of types of human activity - anomic, heteronomic, and autonomous activities - fun is the first step. Creative work, on the contrary, unites the two preceding processes of a lesson and a play, just as autonomy is a kind of synthesis of heteronomy and anomie (Hessen, 1935: 82).

The highlighted triad should be seen as a development of a three-step scheme of the education process presented in Sozialpädagogik. ${ }^{30}$ The task of the first level is to manage the originally anomic sensory desires; the task of the second is to direct the initially completely heteronomic will towards autonomic goals. The task of the third process is to educate the fully autonomous

${ }^{29}$ It is more or less visible in various fragments of this author's analysis (compare esp.: Natorp, 1909b: 317-318; Natorp, 1911: 163; Natorp, 1912b: 198). For the German philosopher, anomie is a state of non-observance of the laws that automatically transforms into heteronomy. The latter is the complete opposite of autonomy. When later, that is, while writing Sozialidealismus, Natorp considered children's creativity to be a constitutive stage for human creativity, he didn't associate child's play with anomie, but with direct, intuitive openness and sensitivity.

${ }^{30}$ Natorp elicited this scheme from Plato's Republic and the theory of virtues presented in this dialogue. The context of Plato's theory of virtues remains important for Hessen (cf. footnote 15 above). However, this is not within scope of this paper to compare these two authors' theory of virtues. 
rational will that is targeted at the creative realization of cultural values. ${ }^{31}$ The anomie of children's play is characteristic for the first level; for the second, the heteronomy, which is characterized by working in the school classroom; and for the third, self-education and self-determination, which can possibly be transformed into the autonomous creative work (at the higher levels, college-level of education). The author of Foundations of pedagogy also emphasized as Natorp did in his Sozialidealismus - the importance of intuition. It is only in an individual, intuitive experience that one can understand all the important components of culture in their mutual dialectical relationship. ${ }^{32}$ The intuitive experience of this relationship - its recognition - cannot be reduced to understanding the abstract generality of laws opposed to what is particular. Rather, it is intuitively perceived totality (pleroma), into which:

the subjugated it particularity is seemingly poured into; the particularity is poured into totality as fun is poured into the lesson, and the lesson is poured into the work, or as force is poured into authority, which on its part seeks to transform itself into a fullness of freedom, absorbing into it the previous levels and thus removing their one-sided nature (Hessen, 1935: 390).

Philosophy, Hessen argued, can only achieve this intuitive fullness of understanding in its practical application to everyday life, that is, only as pedagogy. The very moment of application, or the specific "technique"33 characteristic for philosophy, cannot be reduced to the application of certain technical or didactic measures according to some instruction. It finds its proper expression "in the impulse of creativity" (Hessen, 1935: 308). In its most elementary form, this impulse must mean the purely practical and therefore moral work of

${ }^{31}$ Contrary to Natorp and Dewey, Hessen recognizes the autonomous validity of cultural values. He distinguished the latter from the abstract values (ideals, principles), i.e. recognised only by certain subjects, but detached from social reality and thus purely subjective. Autonomous cultural values, on the other hand, are not only subjective, as they constitute timeless (überzeitlcb) values-tasks, independent of the subject's will and emotional states, that provide principles and ideas organically emerging from creatively developed socio-cultural tradition. It is only through this last type of value that "in creative and dynamic human act the past is preserved and passed onto other people in the living chain of efforts targeted at one timeless task" (Hessen, 1930b: 114). The very existence of values cannot be separated from the creative act of their realization. The values can be applied only if they are realized in such acts.

32 Hessen's position should be, therefore, labelled as intuitivism (Lossky, 1952: 321). It should be also emphasized that Hessen distinguishes two types of intuition. The first one relates to the comprehensive, dialectical understanding of some problem, while the second one is strictly practical, expressed in our mode of action. In this context, which will be discussed hereafter, the Russian philosopher speaks about intuition of the will.

${ }^{33}$ In the indicated place (Hessen, 1935: 309), the term "technique" is taken by Hessen in the quotation marks. 
the teacher. In it lies a teacher's true authority, which he is able to transform into full freedom. Authority itself remains an element of a more legal than moral character. Thus, in the educational community, both moments (legal and moral) must remain together in a dialectic tension. The emergence of the communal dimension of the learning process is possible when the teacher not only organizes the work of the students in an appropriate way, but also manages to revive this working community with the creative and moral element of his own personality. In order to properly capture this issue, Hessen introduced (in the book On the contradictions and unity of education, published just before the outbreak of World War II) a four-layer structure in place of the previous three-layer structure of the educational process. An important novelty, as compared to his previous concept, was the addition of a fully separate moral education. It is only through this, argued the Russian philosopher, that the process of education, which takes places in the first three layers, gains its own proper dynamics. $^{34}$

Hessen labelled this last, fourth layer as salvation, grace, or active love. The Russian philosopher uses religious language to describe this concept; however, he states that it is not related to any particular religion, but rather to both a moral and spiritual attitude towards the world and other people. This attitude finds its expression and foundation in the dynamic "intuition of the will" (Hessen, 1968b: 299), through which in a particular action one can capture the moral duty associated with a particular situation and all the persons concerned. In this context, Hessen used the concept of intuition, since a particular moral obligation cannot be captured in more or less abstract conceptual structures. This intuition cannot be reduced and understood as the realization of any predetermined moral or religious ideal. Instead, it constitutes all economic, social and cultural works as "the object of human faith, and therefore subject to man's existence as an individual" (Hessen, 1939: 239).

Thanks to this shared common faith, the work of education undertaken by particular individuals achieves its communal dimension. Hessen described this dimension as the salvation or Kingdom of God. This is understood as a completely new, previously unanticipated (by no methodical or conceptual means), moral and spiritual order of the community, which the teacher is able to create only through his own moral intuition. However, the moral and spiritual commitment of the teacher cannot change the fact that the process of education is always full of dialectical contradictions. At best, teachers' actions can provide

${ }^{34}$ Hessen attributed these first three layers, which is also a novelty when compared to his earlier project, with ontological meaning: the child anomie is ascribed to the layer of natural existence, heteronomy into the layer of social existence, and the autonomy of cultural values, realized at the last level of education is ascribed into the layer of cultural existence. This paper will not cover this issue in more detail. 
a shaky, dynamic balance between antagonistic forces and tensions that govern any particular educational situation. ${ }^{35}$ Hessen wrote:

The contradictions inherent in education cannot be solved by any concept or even a "specific idea", but only by the will, which each time must restore and constantly maintain a shaky balance between antagonistic moments, giving each act of education the character of some immeasurable intensity. The "intuition of the will" rather than the intuition of reason is therefore the only equivalent tool of this no longer Hegelian, but rather Fichte's and Proudhon's dialectic, which is only capable of comprehending the facts of education in their final and internally contradictory depths (Hessen, 1938: 191-192).

Such a shaky balance is a condition for the emergence of a space in which the creative work and expression of students can begin to take shape. However, the educational community in which this shaky balance occurs always remains a legal community. And the creative intuition of the will expressed in the active love of fellow creature is not the ideal of the laws, but it is tolerance towards different worldviews and religious attitudes. The tolerance guaranteed by laws is a prerequisite for all creativity. The educational community needs to create these conditions. However, the educational community can only create it to the extent as it remains a community "created from the bottom-up and from within" (Hessen, 1939: 151); that is, allowing all interested parties, including students, to work on the organisation of school life. Hessen pointed out that the author of Sozialidealismus was the one who introduced postulate of socialization of education. Although his own proposal with regard to detailed solutions may raise some objections, the postulate itself remains completely valid. ${ }^{36}$ In this respect, the pedagogical projects of the two authors clearly have some common perspective.

\section{CONCLUSION}

All three conceptions of pedagogy as an applied philosophy presented above revolve around the communal experience of creative work. The communal experience of creative work should be a pillar of the educational community, participation in which is a fundamental condition of the educational process. For the three authors considered in this paper, it is clear that all social engagement and understanding that underpins the creation of various forms of social life are rooted in this experience. However, this does not change the fact that the existing forms and structures of social interaction must, from this

${ }^{35}$ The Hessen concept of dialectics has been thoroughly discussed in the work: Folkierska, 2005.

${ }^{36}$ In his work On contradictions and unity of education, Hessen accused Natorp of "exuberant parliamentarism" (Hessen, 1939: 152). This allegation had not yet appeared in an earlier discussion of the subject, Foundations of pedagogy (Hessen, 1935: 196-197). 
perspective - that is, always temporary, impermanent and accessible only by creative intuition - be considered incomplete and imperfect. A community of full participation and full understanding in real social life always appears for this reason as a lost community, i.e. as a never fully fulfilled idea. ${ }^{37}$ If the creative potential of this community is to be reconstructed in some way in the dynamics of social change, then this reconstruction must, first of all, be undertaken over and over again; secondly, it must rely primarily on removing obstacles that hamper the communal potential of human creativity. The intuitive - and, in this sense, contemplative - experience of the creative work is the right "dialectical counterweight" ${ }^{38}$ to use Hessen's words, to all human activity narrowed to its instrumental dimension. The contemplative nature of this experience does not mean that it is passive, but instead refers to the immediacy of the intuitive opening of the subject to the whole world and the whole world to the subject. It is only through this opening - and all three authors again agree with each other in this matter - that the subject is able to go for a moment beyond the existing social constraints and stratification and aspire to re-reconstruct (renew) the structures of social life. ${ }^{39}$ To the extent that peda-

37 With regard to Dewey's work The public and its problems, the issue was discussed in the article: Joas, 1993. In this work, Dewey considers democracy not so much as one of the many possible social ideals towards which social life can be pursued, but as the ideal of community which creates condition of all forms of social life: "Regarded as an idea, democracy is not alternative to other principles of associated life. It is the idea of community life itself. It is an ideal in the only intelligible sense of an ideal: namely, the tendency and movement of same thing which exists carried to its final limit, viewed as completed, perfected" (Dewey, 1988b: 328). This ideal of community is, as Dewey pointed out, the subject of the "common faith of mankind" (Dewey, 1989a: 58). It is a religious belief freed from all the dogmatic assumptions present in historical religions. There is at least one serious caveat to this concept. The question arises whether the belief in the ideal of a democratic community, even if it is treated in the context of the religious quality of experience as "the widest and deepest symbol of the mysterious totality of being the imagination calls universe" (Dewey, 1989b: 56), is not too one-sidedly focused on the communal dimension of life, thus it is losing almost entirely the problem of the existence of the individual. Natorp and Hessen, exploring the religious dimension of social life much more clearly, stressed that only the inclusion of the individual dimension shows not only how the individuals are rooted in the community, but also the specificity of the individual way of being of each and every one who participates in that community. Dewey's concept of democracy does not take into account this individual aspect, and thus it is excessively unilateral. The problem is that democratic institutions, as Dewey himself acknowledged at one point, are not a sufficient guarantee of the existence of democratically minded and functioning subjects. Only the latter are able to ensure the viability of the former, not the other way around (Dewey, 1991: 91-92).

${ }_{38}$ See Hessen's objection to Dewey's pragmatism quoted in Preliminary remarks (Hessen, 1930a: 679, 683).

${ }^{39}$ It also should be noted that this intuitive opening, constituting both an essential point of the act of expression as well as a proper criterion for all social reconstructions, remains, in terms of its structure and function, the same, regardless if we consider the transcendental (Natorp, Hessen) or detranscendentalised (Dewey) variant of pedagogy as an applied philosophy. 
gogy is able to allow this experience to be acknowledged, it becomes a fully applied philosophy. The very moment of application triggers the critical potential inherent in such pedagogy. Based on this potential, repeated reconstruction of social practices can be conducted. Therefore, all pedagogy in its concrete, practical application must be a critical pedagogy. This conclusion can be drawn from the analyses presented by all three authors considered in this paper.

\section{BIBLIOGRAPHY}

Daniłkina, N.W. (2009). Stanowlenie teorii obrazowania S.I. Hessena kak „prikładnoji fiłosofii”. Wiestnik Leningradskogo Gosudarstwennogo Uniwersiteta im. A.S. Puszkina, $1(4), 233-241$.

Dewey, J. (1975). Kant and philosophic method (pp. 34-47). In: J. Dewey. The early works of Jobn Dewey 1882-1898 (vol. 1). (J.A. Boydston, Ed.). Carbondale-Edwardsville: Southern Illinois University Press.

Dewey, J. (1985). Democracy and education. In: J. Dewey. The middle works of John Dewey 1899-1924 (vol. 9). (J.A. Boydston, Ed.). Carbondale-Edwardsville: Southern Illinois University Press.

Dewey, J. (1988a). Experience and nature. In: J. Dewey. The middle works of John Dewey 18991924 (vol. 1). (J.A. Boydston, Ed.). Carbondale-Edwardsville: Southern Illinois University Press.

Dewey, J. (1988b). The public and its problems (pp. 235-372). In: J. Dewey. The later works 1925-1953 (vol. 2). (J.A. Boydston, Ed.). Carbondale-Edwardsville: Southern Illinois University Press.

Dewey, J. (1989a). A common faith (pp. 1-58). In:J. Dewey. The later works 1925-1953 (vol. 9). (J.A. Boydston, Ed.). Carbondale-Edwardsville: Southern Illinois University Press.

Dewey, J. (1989b). Art as experience. In: J. Dewey. The middle works of John Dewey 1899-1924 (vol. 10). (J.A. Boydston, Ed.). Carbondale-Edwardsville: Southern Illinois University Press.

Dewey, J. (1991). I believe (pp. 91-97). In: J. Dewey. The later works 1925-1953 (vol. 14). (J.A. Boydston, Ed.). Carbondale-Edwardsville: Southern Illinois University Press.

Folkierska, A. (2005). Sergiusz Hessen - pedagog odpowiedzialny. Warszawa: Wydawnictwa Uniwersytetu Warszawskiego.

Habermas, J. (2008). Between naturalism and religion. (C. Cronin, Trans.). Cambridge: Polity Press.

Hessen, S. (1923). Osnovy pedagogiki. Vvedenie v prikladnû̂ filosofiû. Berlin: Kn-vo Slovo.

Hessen, S. (1924). Paul Natorp. Russkaja Škola za Rubežom, 2(10/11), 1-8.

Hessen, S. (1930a). John Deweys Erziehungslehre. Erziebung. Monatschrift für den Zusammenbang von Kultur und Erziebung in Wissenschaft und Leben, 5, 657-684.

Hessen, S. (1930b). Der Zusammenbruch des Utopismus (pp. 107-120). In: B. Jakovenko (Ed.). Festschrift Th. G. Masaryk zum 80. Geburtstage. Erster Teil. Bonn: Friedrich Cohen.

Hessen, S. (1935). Podstawy pedagogiki. (A. Zieleńczyk, Trans.). Warszawa: Nasza Księgarnia.

Hessen, S. (1938). Szkoła i demokracja na przełomie. (A. Zieleńczyk, Trans.). Warszawa: Nasza Księgarnia.

Hessen, S. (1939). O sprzecznościach i jedności wychowania. Zagadnienia pedagogiki personalistycznej. Lwów-Warszawa: Książnica-Atlas. 
Hessen, S. (1968a). Cnoty starożytne a cnoty ewangeliczne (pp. 194-268). In: S. Hessen. Studia z filozofii kultury. (A. Walicki, Ed.). Warszawa: Państwowe Wydawnictwo Naukowe. Hessen, S. (1968b). Prawo i moralność (pp. 269-313). In: S. Hessen. Studia z filozofii kultury. (A. Walicki, Ed.). Warszawa: Państwowe Wydawnictwo Naukowe.

Hessen, S. (1997). Pedagog (pp. 70-93). In: S. Hessen. Pisma pomniejsze. (W. Okoń, Ed.). Warszawa: Wydawnictwo „Zak”.

Jagelka, N. (1992). Paul Natorp. Philosopbie, Pädagogik, Politik. Würzburg: Königshausen \& Neumann.

Joas, H. (1993). Gemeinschaft und Demokratie in den USA. Die vergessene Vorgeschichte der Kommunitarismus-Diskussion (pp. 49-62). In: M. Brumlik \& H. Brunkhorst (Eds.). Gemeinschaft und Gerechtigkeit. Frankfurt a. M.: Fischer Taschenbuch Verlag.

Joas, H. (1997). The creativity of action. (J. Gaines \& P. Keast, Trans.). Chicago: University of Chicago Press.

Joas, H. (2000). The genesis of values. (G. Moore, Trans.). Chicago: University of Chicago Press.

Lembeck, K.-H. (1994). Platon in Marburg: Platon-Rezeption und Philosophiegeschichtspbilosophie bei Cohen und Natorp. Würzburg: Königshausen \& Neumann.

Lossky, N.O. (1952). History of Russian philosophy. London: George Allen and Unwin.

Müller, C. (2005). Sozialpädagogik als Erziebung zur Demokratie - ein problemgeschichtlicher Theorieentwurf. Bad Heilbrunn: Klinkhardt.

Natorp, P. (1888). Einleitung in die Psychologie nach kritischer Methode. Freiburg: J.C.B. Mohr (Siebeck).

Natorp, P. (1907). Gesammelte Abhandlungen zur Sozialpädagogik. Stuttgart: Frommann.

Natorp, P. (1909a). Pestalozzi. Sein Leben und seine Ideen. Leipzig: Teubner.

Natorp, P. (1909b). Philosopbie und Pädagogik. Untersuchungen auf ibrem Grenzgebiet. Marburg: N.G. Elwert'sche Verlagsbuchhandlung, G. Braun.

Natorp, P. (1911). Volkskultur und Persönlicbkeitskultur. Sechs Vorträge. Leipzig: Quelle und Meyer.

Natorp, P. (1912a). Allgemeine Psychologie nach kritischer Methode. Tübingen: J.C.B. Mohr (Siebeck).

Natorp, P. (1912b). Kant und die Marburger Schule. Kant-Studien, 17, 193-221.

Natorp, P. (1919). Der Idealismus Pestalozzis. Eine Neuuntersuchung der philosophischen Grundlagen seiner Erziebungslebre. Leipzig: Felix Meiner.

Natorp, P. (1920). Sozialpädagogik. Theorie der Willensbildung auf der Grundlage der Gemeinschaft. Stuttgart: Frommann.

Natorp, P. (1921). Platos Ideenlebre. Zweite, durchgesehene und um einen metakritischen Anbang vermebrte Ausgabe. Leipzig: Felix Meiner Verlag.

Natorp, P. (1922). Sozialidealismus. Neue Richtlinien sozialer Erziebung. Berlin: Springer.

Natorp, P. (1925). Vorlesungen über praktische Philosophie. Erlangen: Verlag der Philosophischen Akademie.

Natorp, P. (1958). Philosophische Systematik. (H. Natorp, Ed.). Hamburg: Felix Meiner.

Sośnicki, K. (1967). Rozwój pedagogiki zachodniej na przełomie XIX i XX wieku. Warszawa: Państwowe Zakłady Wydawnictw Szkolnych.

Walicki, A. (1992). Legal philosopbies of Russian liberalism. Notre Dame: University of Notre Dame Press.

Wilkoszewska, K. (2003). Sztuka jako rytm życia: rekonstrukcja filozofi sztuki Johna Deweya. Kraków: Universitas.

Wieczorek Z. (2005). Filozofia wszechjedności Sergiusza Hessena. Kraków: Wydawnictwo Uniwersytetu Jagiellońskiego. 
